\title{
An Analysis of Residential Arson Fires in Norway
}

\author{
JAN P. STENSAAS and ANNE STEEN HANSEN \\ Norges branntekniske laboratorium as \\ (Norwegian Fire Research Laboratory - a company in the SINTEF group) \\ N-7465 Trondheim, Norway
}

\begin{abstract}
This paper describes an analysis of residential ${ }^{1}$ arson fires in Norway in 1996 and 1997. The police have categorised 417 residential fires as arson for these two years. The case documents of 371 or 90 $\%$ of these fires have been examined and analysed thoroughly with respect to finding characteristic features of these fires as well as the leading motives of the firesetters. These case documents have been examined in order to record such data of residential arson fires as for example: The time of the fire (hour, day of the week, month), type of building, location of the fire (city, town, village, countryside), age and sex of the arsonist, whether the arsonist was intoxicated or not, arson indicators (multiple fires, accelerants, trailers, unusual fuel load etc), fire losses (property fire losses, deaths and injuries), the motive for arson, whether the case resulted in conviction or whether the case was dropped. The paper presents the results with respect to typical characteristics and features of residential arson fires in Norway for these two years. However, there is nothing that indicates that these two years are not typical.
\end{abstract}

KEY WORDS: arson, residential fires, profiles of arson, motives for arson

\section{INTRODUCTION}

According to the instructions from the prosecuting authority in Norway the police shall investigate all fires in order to find the cause of the fire. This applies even though there is no suspicion of arson. Norway is a small country with only 4.5 million inhabitants. According to statistics from the Directorate of Fire and Explosions Prevention the police in Norway have investigated somewhat more than 4000 residential fires in 1996 and 1997. About $10 \%$ of these fires were categorised as arson.

The case documents of 371 residential arson fires have been examined in this analysis ${ }^{2}$. This number constitutes approximately $90 \%$ of the residential arson fires investigated by the police during the two-year period. These case documents, which have formed the data basis of the analysis, have mostly comprised of the police examination of the fire scene, interrogations, the report from the fire service, the report from the local electricity supervision, appraisals of the insurance companies and different expert opinions. The objective of this analysis have been to find the characteristics of arson in residences and to establish a 'profile' of such fires, which describes typical features and criteria of residential arson fires.

1 That is, fires in private houses which involve single family houses, row houses, multi-family houses, apartment buildings and holiday houses (holiday cottages, huts, cabins, etc). 


\section{DEFINITION OF ARSON}

In this study the same definition of arson is applied as used by a working group appointed by the Department of Justice in Norway in $1994^{3}$. That is, voluntarily, and wilfully setting fire to a residence. Hence, fires that are due to carelessness or misfortune are not defined as arson. On the other hand, firesetters that do not have any specific motive for setting fire to a residence, like for instance children playing with fire, mentally deranged ${ }^{1}$ persons or persons that have an impaired discernment ${ }^{2}$ are, however, defined as arson by the working group [3].

\section{MOTIVES FOR ARSON}

In the case documents the motive for arson was rarely explicitly described. Hence, the motive of the arson was derived from the case documents. In 65 of the 371 arson fires examined, i.e. in $18 \%$ of the examined fires, it was not possible to find an exact motive for the arson. Table I shows the distribution of the predominant motives for the 306 residential arson fires where it was possible to find a motive for arson. It appears from the table that in more than half of the arson fires the lack of motive was the indisputable predominant 'motive' for arson. That is, the arsonist did not have any specific motive for deliberately setting fire to the residence. These fires were due to either children playing with fire, mentally deranged persons or persons that have an impaired discernment. The lack of motive is in this paper defined as a 'motive' for arson.

Table I - The distribution of the predominant motives for the 306 arson fires in residences in Norway in 1996 and 1997 with a "known" motive for the arson.

\begin{tabular}{|l|c|c|}
\hline \multicolumn{1}{|c|}{ Predominant motives for arson } & Number of fires & In \% \\
\hline Lack of motive: & 157 & 51.3 \\
\hline Vandalism: & 93 & 30.4 \\
\hline Profit: & 17 & 5.6 \\
\hline Revenge: & 17 & 5.6 \\
\hline Suicide: & $17^{3}$ & 5.6 \\
\hline The hero syndrome/the motive of attention: & 3 & 1.0 \\
\hline Political/ideological motivated: & 2 & 0.7 \\
\hline Sum: & 306 & 100.0 \\
\hline
\end{tabular}

It appears that vandalism represented slightly more than $30 \%$ of the arson fires in the two years' period. Thus, the lack of motive and vandalism represented together more than $80 \%$ of the motives of the arson fires.

The profit motive, which by many people is believed to be the predominant motive for residential arson fires, represented only slightly less than $5 \%$ of the fires. Arson fires in connection with revenge and suicide constituted the same percentage as the profit motive. The motive of attention (also called the hero syndrome) and the political/ideological motivated arsonist represented both roughly $1 \%$ of the residential arson fires.

1 Mentally deranged persons involve all kinds of people that have a degree of departure from mentally normal persons. That is, from people that have mild mental diseases to people that have a strong psychosis. Common for all those persons is that the mental state has been decisive for setting fire in the residence.

2 Persons with impaired discernment are people that have lost the ability to judge well due to the use of intoxicating substances, senile dementia or they are mentally retarded persons.

3 In five of these 17 fires the arsonist succeeded in committing suicide due to the fire. 


\begin{tabular}{|c|c|c|c|c|}
\hline \multirow[b]{2}{*}{$\begin{array}{l}\text { MOTIVE/ } \\
\text { characteristic }\end{array}$} & \multirow[b]{2}{*}{ VANDALISM } & \multicolumn{3}{|c|}{ LACK OF MOTIVE } \\
\hline & & $\begin{array}{c}\text { Children } \\
\text { playing with } \\
\text { fire }\end{array}$ & $\begin{array}{l}\text { Persons with } \\
\text { impaired } \\
\text { discernment }\end{array}$ & $\begin{array}{c}\text { Persons that } \\
\text { are mentally } \\
\text { deranged }\end{array}$ \\
\hline Type of building: & $\begin{array}{l}\text { Apartment } \\
\text { buildings ( } 73 \\
\%)\end{array}$ & $\begin{array}{l}\text { Apartment } \\
\text { buildings }\end{array}$ & $\begin{array}{l}\text { Single-family } \\
\text { houses }\end{array}$ & $\begin{array}{l}\text { Single-family } \\
\text { houses, apart- } \\
\text { ment buildings }\end{array}$ \\
\hline $\begin{array}{l}\text { The room of fire } \\
\text { origin: }\end{array}$ & $\begin{array}{l}\text { Entryways, } \\
\text { corridors, refuse } \\
\text { storage } \\
\text { chambers in } \\
\text { apartment } \\
\text { buildings } \\
(80 \%)\end{array}$ & $\begin{array}{l}\text { Living room } \\
\quad(23 \%)\end{array}$ & $\begin{array}{l}\text { Living room } \\
\quad(33 \%)\end{array}$ & $\begin{array}{l}\text { Living room } \\
\quad(35 \%)\end{array}$ \\
\hline When: & $20: 00-24: 00$ & $16: 00-20: 00$ & 00:00-04:00 & $16: 00-20: 00$ \\
\hline Who: & $\begin{array}{l}\text { Unknown (90 } \\
\% \text { ), but proba- } \\
\text { bly youth } \\
\text { looking for } \\
\text { excitement }\end{array}$ & $\begin{array}{l}\text { Children of the } \\
\text { owner of the } \\
\text { residence ( } 27 \\
\%) \text {, children in } \\
\text { the neighbour- } \\
\text { hood }(27 \%)\end{array}$ & $\begin{array}{l}\text { Unknown } \\
(21 \%)\end{array}$ & $\begin{array}{l}\text { Owner of the } \\
\text { residence } \\
(50 \%)\end{array}$ \\
\hline Age of arsonist: & $\begin{array}{c}\text { Unknown (90 } \\
\%), \text { most likely } \\
10-14 \\
\end{array}$ & $10-14$ & $\begin{array}{c}\text { Around } 40 \\
\text { (middle-aged) }\end{array}$ & $\begin{array}{c}\text { Around } 40 \\
\text { (middle-aged) }\end{array}$ \\
\hline Sex: & $\begin{array}{l}\text { Unknown (90 } \\
\%) \text {, most likely } \\
\text { a boy }\end{array}$ & A boy $(90 \%)$ & $A \operatorname{man}(72 \%)$ & $\begin{array}{c}\text { A woman }(53 \\
\%)\end{array}$ \\
\hline Intoxicated? & Unknown & No $(100 \%)$ & Yes $(84 \%)$ & No $(82 \%)$ \\
\hline Arson indicators: & No/rare & $\begin{array}{l}\text { Matches and } \\
\text { lighters }\end{array}$ & $\begin{array}{l}\text { Matches and } \\
\text { lighters }\end{array}$ & $\begin{array}{l}\text { Matches and } \\
\text { lighters, liquid } \\
\text { accelerants }\end{array}$ \\
\hline $\begin{array}{l}\text { Degree of crime not } \\
\text { prosecuted: }\end{array}$ & $99 \%$ & $100 \%$ & $72 \%$ & $90 \%$ \\
\hline $\begin{array}{l}\text { Reasons for } \\
\text { dropping the case: }\end{array}$ & $\begin{array}{l}\text { Lack of infor- } \\
\text { mation of the } \\
\text { perpetrator } \\
(82 \%)\end{array}$ & $\begin{array}{l}\text { The perpetrator } \\
\text { is under fifteen } \\
\text { years of age ( } 66 \\
\%)\end{array}$ & $\begin{array}{l}\text { 1. Lack of infor- } \\
\text { mation of the } \\
\text { perpetrator, } 2 \text {. } \\
\text { Due to the state } \\
\text { of the evidence }\end{array}$ & $\begin{array}{l}\text { Doubt about } \\
\text { the sanity of } \\
\text { the perpetrator } \\
\text { at the time of } \\
\text { crime }(49 \%)\end{array}$ \\
\hline $\begin{array}{l}\text { Percentage of fires } \\
\text { with fire losses less } \\
\text { than } \$ 1000:\end{array}$ & $73 \%$ & $50 \%$ & $62 \%$ & $50 \%$ \\
\hline $\begin{array}{l}\text { Percentage of fires } \\
\text { with fire losses } \\
\text { greater than } \\
\text { \$25000: }\end{array}$ & $17 \%$ & $23 \%$ & $15 \%$ & $21 \%$ \\
\hline
\end{tabular}

Fires that have started in a trash container stored in refuse storage chambers, a bill on a notice board, in a newspaper or magazine in a corridor, baby carriage bag or a bicycle in the entryways in apartment buildings, were defined as an arson fire by vandalism if there were no other motives or reasons for the arson. In $90 \%$ of these cases the arsonist remained unknown. There are reasons to believe that young people looking for excitement have caused these fires, even though this statement is not supported directly by the examined case documents. 


\section{DEATHS AND PERSONAL INJURIES}

In as much as $95 \%$ of the residential arson fires there were no personal injuries. Among the remaining $5 \%$ of the fires twelve persons were injured due to inhalation of smoke and nine persons had burns.

A total of eight persons were killed in six residential arson fires, one death in 1996 and seven deaths in 1997. In five fires one person was killed (i.e. the five fires in which the motive for arson was to commit suicide), while in one fire three persons were killed. In the latter fire the three lost persons were due to children playing with fire. Five of the fatalities occurred because the arsonist succeeded in committing suicide.

There were an average number of four deaths per year in 1996 and 1997 compared to an average number of 50 deaths in residential fires in general. That implies that there were a slightly smaller number of fatalities in residential arson fires compared to fires in residences in general, when knowing that residential arson fires represent approximately $10 \%$ of all residential fires.

\section{PROPERTY LOSSES}

After each fire the fire service provides estimates of the property fire losses due to the fire, i.e. estimates of the costs to rebuild the residence to its original state. Fig. 1 shows the distribution with respect to the fraction of fires that fall into six different intervals of estimated fire losses. That is, approximately zero costs (fires with no turnout of the fire service because the fire was extinguished by the residents, neighbours, people passing by etc), $\$ 0-1000, \$ 1000-10000, \$ 10000-25000, \$ 25$ 000-50 000 and greater than $\$ 50000$ (in US \$).

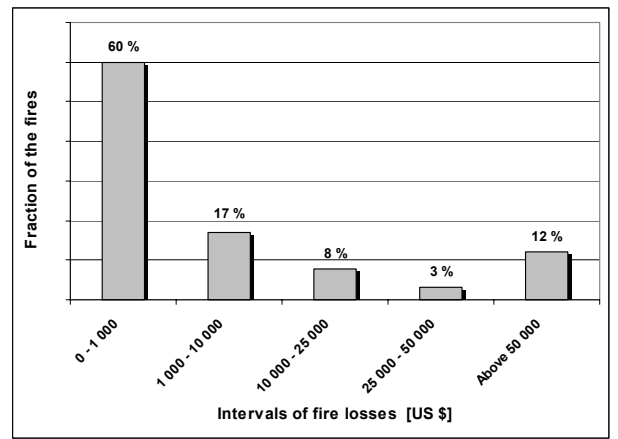

Fig. 1 - Estimated losses due to arson fires in residences in Norway in 1996 and 1997.

It appears from Fig. 1 that in $60 \%$ of the arson fires the fire loss estimates of the fire service were less than $\$ 1000$. The fire losses were greater than $\$ 50000$ in only $12 \%$ of the fires. A comparison between the fire loss estimates of the fire service and the insurance payments has shown that the maximum values of the loss estimates were of the same magnitude as the payments of the insurance companies. In spite of this it can be concluded that the losses due to arson fires in residences were rather modest. It seemed as if the intent of by far the great number of the arson fires was not to destroy the residence, but rather a spontaneous act caused due to child fireplay, by people in a mental crisis or by intoxicated persons. These fires were most often rapidly extinguished by either the arsonist or by some of the other residents. 
Residential arson fires motivated from vandalism caused not at all high property losses. In fact, as shown in Table II, these fires resulted in the smallest property loss of all motives for residential arson fires. The fire losses of fires caused by vandalism are less than $\$ 1000$ in as much as $73 \%$ of the fires. The losses were above $\$ 25000$ in only $17 \%$ of the fires.

The reason for this is that these fires occur mostly in areas with either small amounts of highly combustible materials (i.e. entryway, stairs and corridors in apartment buildings), or in areas with no highly valuable properties (i.e. refuse storage chambers in apartment buildings). It is supposed that the intention of these firesettings was not to cause a lot of damage, but just a little excitement for young people. Thus, arson fires in single family houses and holiday houses resulted in substantially higher losses than the losses in apartment buildings. While more than $70 \%$ of the fires in the latter type of buildings caused minor fire losses, only $25 \%$ of the fires in single family houses caused minor losses.

\section{THE LOCATIONS OF ARSON FIRES}

Figure 2 shows the locations of arson fires. It appears that almost half of the fires occurs in a city (i.e. one of the four largest 'cities' in Norway with more than 100000 inhabitants). Slightly more than each fifth arson fire occurred in towns and $16 \%$ of the fires occurred in villages (densely populated areas) or at the countryside. Hence, arson fires seem primarily to be a problem in the four largest cities in Norway with a total population of slightly less than 1 million or roughly one-fifth of the population in Norway.

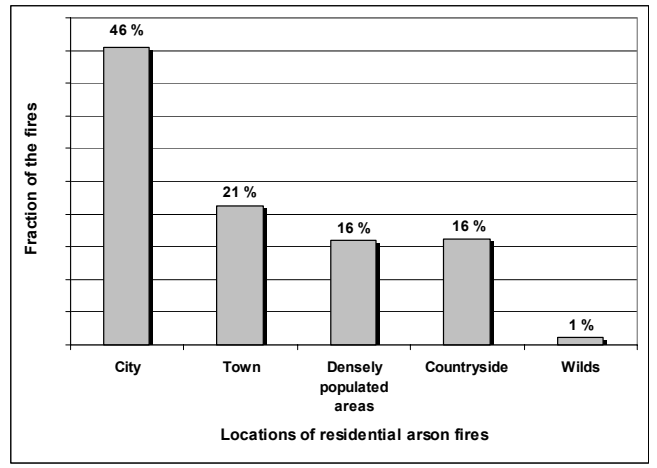

Fig. 2 - The fraction of fires according to the location of the fire.

\section{TYPE OF BUILDING IN RESIDENTIAL ARSON FIRES}

Figure 3 shows the fraction of arson in different types of residences. It appears that by far the great fraction of arson in residences occur in apartment buildings and single-family houses. Almost $80 \%$ of the fires took place in these two types of residences. However, the number of flats of these buildings in Norway is also significantly higher compared to other types of buildings. 


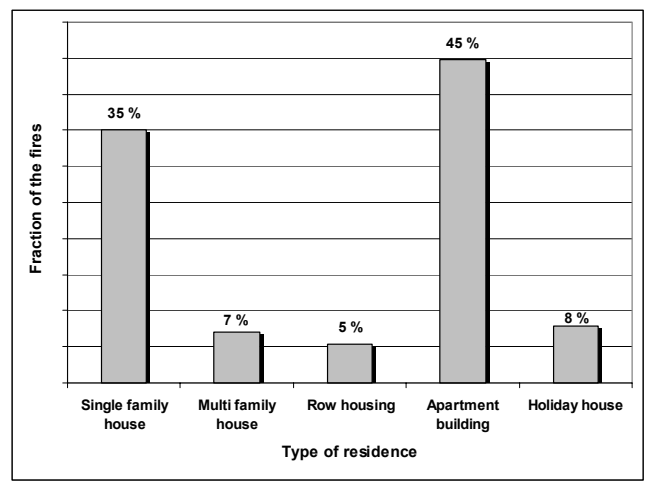

Fig. 3 - The fraction of arson according to the type of residence.

If the number of arson fires of each building type is divided by the actual number of flats of each building type, the following estimates result:

- Single family houses:

- Row houses:

- Multi-family houses:

- Holiday houses ${ }^{1}$ :

- Apartment buildings:
12.8 fires per 100000 flats

42.4

It appears that the frequency of arson in apartment buildings and holiday houses is roughly three times as high as in smaller residential occupancies like single family houses and row houses.

$12 \%$ of the arson fires in residences occurred in unoccupied or left houses. Such types of buildings represent, however, a significantly smaller fraction of the total number of residences in Norway than $12 \%$. Hence, the probability of having an arson fire in an unoccupied building is considerably higher than in occupied buildings. The main reason for this appears to be that such buildings are not sufficiently secured against housebreaking. These buildings are popular places for children, young people, hobos, drug addicts etc. Such people may light a fire, which can result in fire in the building. These fires are defined as arson fires by the authorities in Norway. Hence, it is very important to secure unoccupied residences against such intruders. In many of these cases the police found residues which indicated alcohol and drug abuse, e.g. empty bottles or equipment for the use of narcotic substances. Consequently, it was assumed that persons with impaired discernment were responsible for these firesettings.

\section{TIMES OF ARSON FIRES}

Table III shows an overview of the distribution of the number of firesettings during the 42 four-hour intervals during a week. It can be seen that most of the arson fires in residences occur between 20:00 and 04:00, with almost half (45\%) of the fires. Further that arson fires take place most frequently during the first four hours after midnight on Saturday. The number of fires during this four-hour interval was 21 , which is 2,4 times or $140 \%$ higher than the average number of 8.7 fires. One reason, which clearly appears from this analysis, is that arson carried out by adults to a high degree is drug related, usually by misuse of alcohol. In contrast the number of arson fires on Friday and Saturday in the time interval 08:00-12:00 in the morning was only 2.

1 Holiday cottage, hut, lodge or cabin used by families and others in the weekends, during the Easter and the summer holidays. 
Table III - A 'time table' for residential arson fires during the week.

\begin{tabular}{|c|c|c|c|c|c|c|c|c|}
\hline $\begin{array}{c}\text { The time } \\
\text { interval }\end{array}$ & $\begin{array}{c}\text { Mon- } \\
\text { day }\end{array}$ & $\begin{array}{c}\text { Tues- } \\
\text { day }\end{array}$ & $\begin{array}{c}\text { Wedne } \\
\text { sday }\end{array}$ & $\begin{array}{c}\text { Thurs- } \\
\text { day }\end{array}$ & Friday & $\begin{array}{c}\text { Satur- } \\
\text { day }\end{array}$ & Sunday & \\
\hline $0-4$ & 8 & 4 & 14 & 10 & 5 & 14 & $\underline{\mathbf{2 1}}$ & $\mathbf{7 6}$ \\
\hline $4-8$ & 5 & 3 & 9 & 7 & 8 & 10 & 13 & 55 \\
\hline $8-12$ & 3 & 4 & 4 & 9 & 2 & 2 & 7 & 31 \\
\hline $12-16$ & 10 & 3 & 4 & 6 & 8 & 9 & 5 & 45 \\
\hline $16-20$ & 15 & 9 & 6 & 9 & 8 & 11 & 16 & 74 \\
\hline $20-24$ & 11 & 13 & 11 & 12 & 14 & 12 & 12 & $\mathbf{8 5}$ \\
\hline Sum: & 52 & 36 & 48 & 53 & 45 & 58 & $\mathbf{7 4}$ & $366^{1}$ \\
\hline
\end{tabular}

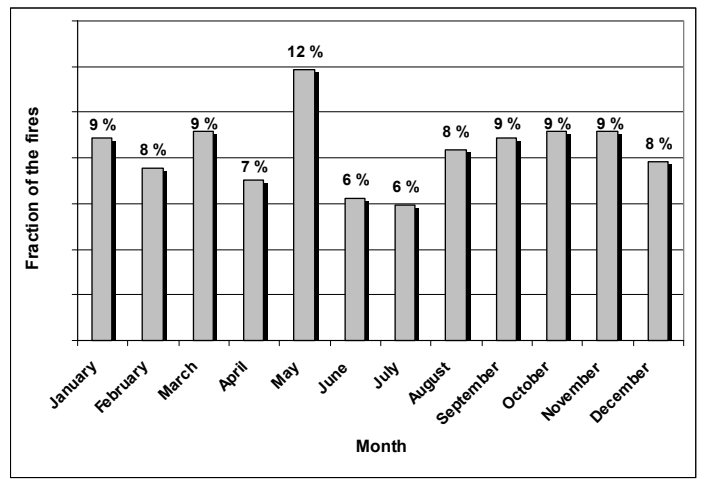

Fig. 4 - The fraction of the total number of residential arson fires (371) for each month for the years 1996 and 1997.

It appears from Fig. 4 that May is the month with the largest fraction of residential arson fires. The fraction of fires in May is twice as high as the fraction of fires during the two subsequent months June and July. It appears also from Fig. 4 that the fraction of arson fires in December is somewhat below the average fraction of $8,3 \%$ of the fires analysed. This is in contrast to fires in residences in general. In Norway December is the month with most of the residential fires. Historically this has been related primarily to the frequent use of candles in connection with the Christmas preparations and celebration.

\section{WHO IS THE ARSONIST?}

The person who was the arsonist was only known in the 98 cases in which there was a confession of the arson and to a certain degree in the 22 cases in which the arsonist was found guilty in arson. In the other cases the arsonist was assumed to be the person suspected or charged with arson by the police.

The definitely largest group of arsonists is firesetters that remained unknown. These arsonists were responsible for $45 \%$ of the arson fires. Vandalism is supposed to be the motive for the major part of these fires. However, if we exclude the unknown arsonist, the owner of the residence started the fire in $29 \%$ of the cases in which the arsonist was a known person, followed by children below 15 years

1 In five of the 371 fires the hour of the day was unknown. 
of age ( $23 \%$ of the fires), tenant $(11 \%)$ and young people in the neighbourhood $(11 \%)$. The latter group of firesetters was young people observed in the area immediately before or after the outbreak of the fire. The police rarely caught these persons, who were assumed by the police to be the firesetters.

\section{THE AGE, SEX AND THE MENTAL STATE OF THE ARSONIST}

Figure 5 shows that the arsonists between 30 and 40 year of age were responsible for the most of the arson fires (50 fires), followed by arsonist between 10 and 20 years of age (45 fires). One fourth of the known arsonists were between 30 and 40 . Almost $40 \%$ of the arsonists of this age group were intoxicated. Roughly the same fraction of the arsonists of the age groups 20-30 and 40-50 year of age were also intoxicated. While arsonists in the age group between 15-50 were responsible for 64 $\%$ of the fires, arsonists in the age group below 15 years caused $28 \%$ of the fires. Neither of the known arsonists below 15 years of age were intoxicated. Firesetters above 50 years of age were responsible for only for $8 \%$ of the arson fires.

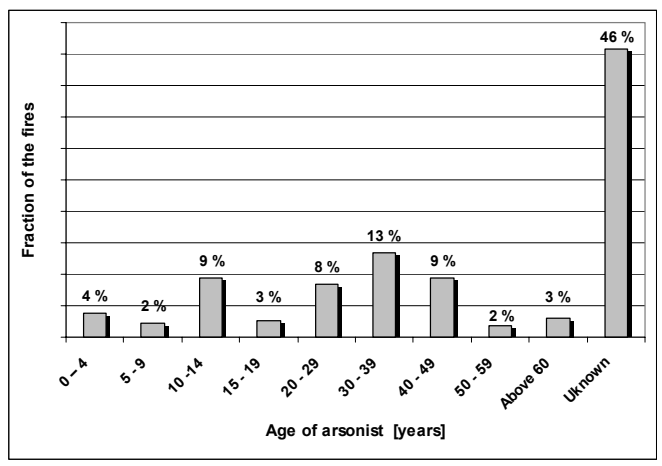

Fig. 5 - The age distribution of the arsonists of residence fires in 1996 and 1997 in Norway.

Figure 6 shows the number of men and women among the arsonists and how many arsonists that were below 15 years of age. It appears that in as much as 160 fires, or $43 \%$ of the arson fires, the sex of the arsonist was not known. It appears also from Fig. 6 that the arsonist was a man in twice as many fires as women or children.

A ratio of 2.0 between men and women was a lower ratio than expected. A ratio of 5.2 between male and female arsonists was found in UK in 1992 and 1993 by Woodward [8]. However, in the former ratio the male arsonists below fifteen years of age were omitted and there was an evident predominance of male arsonists among the young arsonists, i.e. boys under fifteen years of age. If the sex of the latter arsonists is included, the ratio of male to female arsonists is somewhat higher, i.e. 2.7 rather than 2.0, which still is a significantly smaller ratio than found by Woodward.

Approximately $30 \%$ of the known arsonists had an impaired discernment and $30 \%$ were mentally deranged at the time of the arson fire, while $40 \%$ of the known arsonists had a normal state of mind at the act of the crime. 


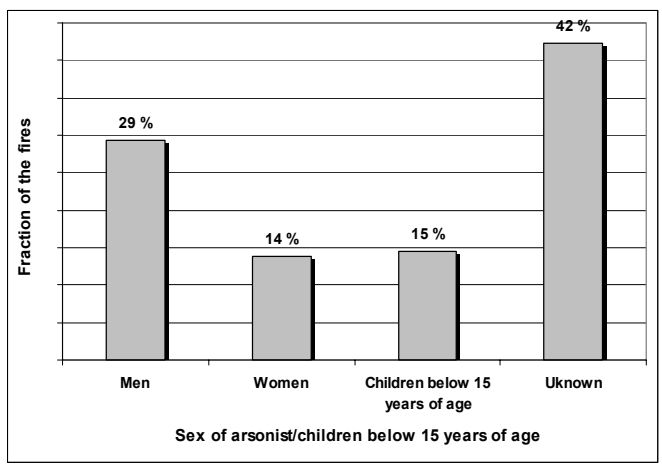

Fig. 6 - The fractions of men and women among the arsonists as well as the fraction of arsonists that were below 15 years of age.

Almost $35 \%$ of the known arsonists were under the influence of intoxicating substances. In about half of the fires with a known arsonist the male arsonist was intoxicated. The female arsonist was intoxicated in every third arson fire she was responsible for. There are reasons to believe that the fires motivated by vandalism, i.e. $30 \%$ of the fires with a known motive, to a certain extent were committed by young people that were intoxicated. Hence, probably as many as $50 \%$ of the arsonists were intoxicated at the time of arson. Due to the fact that almost all the firesetters motivated by vandalism remained unknown, the database does not support the latter two statements. However, the database indicates clearly that arson fires in Norway are closely related to alcohol and drugs.

\section{THE OCCURRENCE OF PYROMANIA}

In $23 \%$ of the residential arson fires with a known arsonist, the arsonist had committed arson at least one time before. In these cases it was almost always persons with impaired discernment or people that were mentally deranged that had committed arson more than once. Hence, these arson fires were not defined as fires due to pyromania. The arson was more a response to certain situations prior to the firesetting and the mental state of the arsonist. Hence, in this analysis there were hardly any of the fires that seemed to be motivated by pyromania in the sense that the motive of the arsonist was to obtain some sort of sensual satisfaction from the fire.

\section{CONVICTION AND CASES DISMISSED BY THE PROSECUTING AUTHORITY}

The 371 arson fires examined were decided in the following way by the prosecution authorities:

- Conviction:

- The case was dismissed due to the following reasons:

- Missing information concerning the perpetrator:

- $\quad$ The suspected person is below 15 years of age:

- Doubt about the sanity of the perpetrator:

- The state of the evidence:

- Lack of evidence:

- $\quad$ Other reasons for dropping the case:

Sum:
22 cases $(6 \%)$

\begin{tabular}{rrr}
156 & “ & $(42 \%)$ \\
44 & “ & $(12 \%)$ \\
43 & “ & $(12 \%)$ \\
39 & “ & $(10 \%)$ \\
34 & “ & $(9 \%)$ \\
32 & “ & $(9 \%)$ \\
\hline 371 cases & $(100 \%)$ \\
\hline
\end{tabular}

It appears that in only $6 \%$ of the arson fires the arsonist was convicted. The rest of the arsons were not brought to the court, but the cases were dropped before they reached that far. The prosecuting authorities dismissed most of the arsons due to missing information concerning the perpetrator. 
This was mainly due to all the firesetters motivated by vandalism, remained unknown. Due to the fact that the fire losses were rather insignificant in the great majority of these cases, the police did not put much effort into the investigation of these fires. Hence, it seemed as if the police or the prosecution authority soon dismissed these cases.

\section{COMPARISON WITH OTHER SIMILAR INVESTIGATIONS}

Similar analyses of building fires in general in Sweden [4], Denmark [5], England [6] and US [7] employ much higher fractions of arson fires. For example, investigations in Denmark, England and US claim that $31 \%, 20 \%$ and $28 \%$ of the building fires are arson fires, respectively. The much smaller fraction of residential arson fires in Norway (i.e. 10\%) may to certain extent be caused by that the Norwegian police only categorise fires that more or less obviously are deliberately set on fire as arson, while the analyses in other countries also include suspicious fires as well. It is also claimed that arson is the leading cause of fires in general in US. However, these arsons are not limited only to residential arsons, but includes all types of arson.

In Norway fires due to electrical fault and the misuse of electrical appliances as well as open flame account both for more than twice as many fires as arson. A reason for the lower fraction of incendiary fires may be that people in the other mentioned countries to a greater extent live in large cities. In Norway there are only four cities with more than 100000 inhabitants. It has been shown both by this analysis and other similar analyses $[4,5]$ that incendiary fires are primarily a major problem in cities.

In the investigations of arson in residences in US it is claimed that such fires represent the second leading cause of fire deaths and by far the leading cause of property damage. It has already been shown in Fig. 1 that $60 \%$ of the incendiary fires caused rather small fire losses, i.e. in the range $\$ 0$ 1000 . The Swedish investigation [4] claims that the main arsonist is a young person. This analysis has shown that persons between 30 and 40 years of age are the main arsonist among the known firesetters, followed by young people between 10 and 20 years of age. However, by assuming that young people mainly cause fires motivated from vandalism (30\% of incendiary fires), this claim may also be valid in Norway. Our analysis shows fairly good agreement with the foreign analyses with respect to other trends shown in this report. Especially the Danish and the Swedish investigations confirm that vandalism and lack of motive are major 'motives' for arson.

\section{DISCUSSION AND CONCLUSIONS}

The police in Norway, which is obligated to investigate all fires in general, has categorised slightly more than $10 \%$ of the residential fires in 1996 and 1997 as residential arson fires. On the basis of this relatively high fraction, residential arson fires must be categorised as a big problem in Norway even though the fraction of residential arson may be somewhat smaller than in some other countries.

The most surprising result of this analysis was that the profit motive was not at all the predominant motive for arson in Norway. Incendiary fires with a lack of motive were the dominating cause of these fires. People who set these latter fires, are children playing with fire, people with impaired discernment or mentally deranged people. These three groups of firesetters were responsible for approximately the same number of incendiary fires and they represented together slightly more than half of the firesettings with a known 'motive'.

Further, this analysis has shown that insurance fraud, which by many is believed to be the main motive for arson, was the motive in only $1-2 \%$ of the incendiary fires. However, incendiary fires motivated from vandalism, which most likely are childish pranks carried out more or less 
spontaneously by young people seeking for a little excitement, accounts for as much as approximately $30 \%$ of the firesettings.

Another surprising result was that residential arson fires do not cause high property losses. In as much $60 \%$ of the fires with a known property loss, the losses were estimated to be in the range $\$ 0-1$ 000 . The fire losses estimated by the fire service were greater than $\$ 50000$ in only $12 \%$ of the incendiary fires.

The main reason for these low property losses is that the great majority of residential arson fires are not deliberately to cause a lot of damage, but it is more about firesettings in connection with persons in mental crisis and the misuse of intoxicating substances, carelessness or negligence. More than 80 $\%$ of the firesettings were either due to children playing with fire, people suffering from mentally crises or diseases or people with impaired discernment and probably due to young people searching for some excitement. Such persons do not deliberately set fire to residential occupancies in order to cause maximum property loss.

Another surprising result was that fire settings due to vandalism caused the smallest fire losses of all residential arson fires. $73 \%$ of these fires caused minor fire losses, i.e. less than $\$ 1000$.

An incendiary fire with a lack of motive is not really arson in the sense that most people put into the word. If these fires are omitted, the problem of residential arson fires is dramatically reduced, i.e. from $10 \%$ to $5 \%$ of all residential fires in Norway. Consequently, it can be concluded that "real" residential arson fires are a much smaller problem than believed originally, at least when it comes to property fire losses and the fraction of residential fires of all residential fires. In addition, it has been shown that residential arson fires have caused slightly fewer deaths than residential fires in general.

This analysis has also shown that residential arson fires mainly occur in the cities with a relative high fraction of apartment buildings, but these fires are obviously not a big problem. At any rate this is valid for fires motivated from insurance fraud. A plausible explanation to this rather low fraction of residential arson fires motivated from insurance fraud (i.e. 1-2 \%) is that there is not much to gain other than a new residence, but presumably a loss of dear belongings.

\section{REFERENCES}

[1] Directorate for Fire and Explosion Prevention: "Brannstatistikk 1997" ("Fire Statistics 1997”), HR-2006, ISSN 1500-6832 (in Norwegian).

[2] Stensaas, J.P.: "Evaluering av boligbranner i 1996 and 1997" ("Evaluation of residential fire in 1996 and 1997”), Norwegian Fires Research Laboratory, Report No. NBL10 A01101, January 2001 (in Norwegian).

[3] Songstad, S.O. m.fl.: "Rapport om tiltak for å forebygge og avdekke påsatte branner" ("Report on measures to prevent and reveal incendiary fires"), a working group appointed by Department of Justice, June 1994 (in Norwegian).

[4] Andersson, H.: "Anlagd Brand - Omfatning och Motiv" ("Incendiary fires - the extent and motives"), Svenska Brandförsvarsföreningen, Report from Brandforsks Project H41, Lidingö 5. September 1991 (in Swedish).

[5] Mikkelsen, H.L.: "Op mod halvdelen af brande i boliger menes å være påsat" ("Up to the half of the residential fires are incendiary fires"), Brandværn nr 6, 1999 (in Danish).

[6] Home Office: "The Prevention of Arson, A report from a working group at Home Office", London 1988.

[7] TriData Corporation: “Arson in the United States", Federal Emergency Management Agency, United States Fire Administration, National Fire Center Report FA 174, August 1997.

[8] Woodward, C.D: "Motiven för anlagd bränder - En analys gjord i England" ("The motives for incendiary fires - An analysis carried out in England”), Arson, No. 1, 1995 (in Swedish). 